\title{
NATURAL ALTERNATIVES TO COCCIDIOSTATS IN RABBIT NUTRITION*
}

\author{
Dorota Kowalska ${ }^{1}$, Paweł Bielański ${ }^{1}$, Paweł Nosal ${ }^{2}$, Jerzy Kowal ${ }^{2}$ \\ ${ }^{1}$ Department of Animal Genetic Resources Conservation, National Research Institute \\ of Animal Production, 32-083 Balice n. Kraków, Poland \\ ${ }^{2}$ Department of Zoology and Ecology, University of Agriculture, Al. Mickiewicza 24/28, \\ 30-059 Kraków, Poland
}

\begin{abstract}
In rabbit management, coccidiosis caused by Eimeria protozoa is a serious health, production and economic problem due to its widespread occurrence. According to Regulation (EC) No 1831/2003 of the European Parliament and of the Council on additives for use in animal nutrition, coccidiostats will be phased out of use by 31 December 2012. This has prompted a search for natural alternatives to coccidiostats, which could stop the progression of this disease. The aim of the study was to identify parasitic invasions in a herd of rabbits before and after the use of natural alternatives to common coccidiostatic drugs and to determine the effect of these alternatives on rabbit performance and meat quality. Different proportions of feed additives based on natural oregano and garlic oils, added to complete diets, had a positive effect on the weight gains of young rabbits during the study from 35 to 90 days of age. In all experimental groups, dressing percentage was higher than the values reported for New Zealand White rabbits, and the feed additives had no effect on the taste of meat samples evaluated. Properly formulated rations of the concentrates reduced the intensity of coccidial infections while protecting the animals against secondary bacterial and viral infections, which usually accompany coccidiosis and are a common cause of mortality. The present results suggest that the herb extracts can be successfully used in prophylaxis as natural alternatives to coccidiostats in feeds.
\end{abstract}

Key words: rabbit, coccidiostats, garlic, oregano, feeding

In rabbit management, coccidiosis caused by Eimeria protozoa is a serious health, production and economic problem due to its widespread occurrence. The intestinal and hepatic forms of coccidiosis are common in this group of animals. Protozoa inhabiting the digestive tract destroy epithelial cells of the intestine and hepatic bile ducts, thus causing digestive disorders, which leads to bloat, diarrhoea, intoxication and damage to the host's body. Eimeria protozoa are highly resistant to the chang-

*This study was supported by the National Centre for Research and Development, project no. 12007810 . 
ing environmental conditions and disinfectants, which makes it almost impossible to eliminate them. Rabbits aged 1 to 3 months are most susceptible to the infection, especially when weaning from mothers in which the disease may be acute and mortality high (Licois, 2004).

In 2000-2010, the results of postmortem examination of rabbits in Polish slaughterhouses were analysed. Out of over 5.6 million rabbits examined, lesions were found in the carcasses of 280686 rabbits (4.94\%), with invasive diseases accounting for $77.95 \%$. In this group of diseases, coccidiosis was the most common $(65.13 \%)$ (Szkucik and Paszkiewicz, 2011).

Coccidiosis is prevented by supplementing feed or water with anticoccidial drugs that inhibit the growth of oocysts. However, coccidia parasites may become drug resistant, which makes the drugs less effective (Pakandl, 2009). Much hope was also placed in vaccines comprising oocysts derived from precocious lines of coccidia species (Licois, 2004; Pakandl, 2009), but this solution was not adopted in rabbit husbandry, probably due to the high costs of application.

In accordance with Regulation (EC) No 1831/2003 of the European Parliament and of the Council on additives for use in animal nutrition, coccidiostats will be phased out of use by 31 December 2012. This has led to the appearance of different natural alternatives to coccidiostats. These include sulphur and sulphates (including copper sulphate), tannic acid, bismuth compounds, thymol, camphor, alum, volatile oils, and preparations from garlic, oregano, sage, caraway, cinnamon, basil or rosemary. Various substances are available that release formaldehyde, which is a disinfectant and a protozoicide but is harmful to animals.

Considering the increasing restrictions on food safety and the ethical aspects of livestock breeding and environmental conservation, it seems most appropriate to find and promote natural coccidiostat alternatives that are friendly to humans and animals. Without question, the largest number of such alternatives is offered by nature itself, but the most difficult task is their selection and practical application in animal production.

Garlic is one of the most researched medicinal plants. A concentrated garlic extract is an excellent feed additive as it aids digestion, improves blood circulation and boosts immunity in animals. It has strong antibacterial, antiviral, antifungal and antiparasitic properties while having anti-inflammatory and disinfecting effects. It owes its efficacy to allicin, an organic compound (phytoncide) released when garlic is crushed.

Oregano has been known as a seasoning for many years. It contains rosmarinic acid, flavonoids, sesquiterpenes, triterpenes, considerable amounts of vitamin $\mathrm{C}$, sterols, oleoresins, and tannins. It is used to produce oregano oil, the active components of which (geranyl acetate, carvacrol, thymol, cymol, borneol, linalool, caryophyllene, and pinene) inhibit the growth of bacteria (including Escherichia coli and Salmonella enterica), pathogenic fungi (Aspergillus, Candida albicans), pathogenic protozoa and some viruses.

The characteristics of the plants mentioned above shows that they can be used for prevention of coccidiosis in farm animals. It must be kept in mind, however, that in preventing coccidiosis it is important to provide animals with proper breeding and 
hygienic conditions and adequate nutrition, and to prevent infections of a chronic and wasting nature, because coccidiosis often develops in animals with compromised immunity. Therefore, preparations that have bactericidal or fungicidal effects, in addition to inhibiting the growth of pathogenic protozoa, seem the most suitable for prophylaxis.

The aim of the study was to identify parasitic invasions in a herd of rabbits before and after the use of natural alternatives to common coccidiostatic drugs and to determine the effect of these alternatives on rabbit performance and meat quality.

\section{Material and methods}

The experiment was carried out at a K-001 rabbit breeding farm belonging to the National Research Institute of Animal Production in Balice, which raises 100 foundation stock females of the New Zealand White breed (NZW).

The study was performed with 140 young rabbits aged between 35 and 90 days. Animals were kept in tiered cages made of wire mesh, with 4 animals of the same sex per cage. The hygienic and technological conditions were in accordance with the general principles of production of this type. Rabbits were subjected to a veterinary prophylaxis programme designed for this group of animals.

From weaning at 35 days to 90 days of age, rabbits in groups (20 animals per group) were fed the following diets ad libitum:

- group I - standard basal diet in pellet form, supplemented with Robenidin (66 $\mathrm{mg} / \mathrm{kg}$ feed) as a coccidiostat;

- group IN - (negative control) standard basal diet without coccidiostat;

- group II - pelleted diet with $0.5 \mathrm{~kg} / 1000 \mathrm{~kg}$ feed of Bell Gold concentrate;

- group III - pelleted diet with $1.00 \mathrm{~kg} / 1000 \mathrm{~kg}$ feed of Bell Gold concentrate;

- group IV - pelleted diet with $0.5 \mathrm{~kg} / 1000 \mathrm{~kg}$ feed of Bell Premium concentrate;

- group V - pelleted diet with $0.75 \mathrm{~kg} / 1000 \mathrm{~kg}$ feed of Bell Premium concentrate;

- group VI - pelleted diet with $0.5 \mathrm{~kg} / 1000 \mathrm{~kg}$ feed of Bell Gold concentrate and $0.3 \mathrm{~kg} / 1000 \mathrm{~kg}$ feed of Bell Premium concentrate.

The standard complete diet fed to rabbits contained soybean meal, wheat bran, ground maize, ground barley, lucerne meal, milk replacer Prelak, $\mathrm{NaCl}$, and a mineral-vitamin premix (LNB Poland Ltd., Kiszkowo). The preparations, which contained $2.5 \%$ natural garlic oil and $1 \%$ oregano oil (Bell Gold) and $0.5 \%$ natural garlic oil and $5 \%$ oregano oil (Bell Premium) on maltodextrin carrier, were purchased from Bellako Ltd. in Zabrze, Poland.

The diets were made according to experimental formulas, and nutrient content was calculated based on Nutritional recommendations and nutritive value of feeds for fur animals (Nutritional recommendations, 2011). Seven subsamples were taken from each batch of the diet to perform basic chemical analyses. Analysis was made of the content of dry matter (SOP* M.011:2006), crude protein (SOP* M.007:2006), 
crude fat (SOP* M.013:2006), crude fibre (SOP* M.012:2006) and ash (SOP* M.014:2007) (*Standard Operation Procedure, $\mathrm{M}$ - number of procedure at the Central Laboratory of the National Research Institute of Animal Production).

The following parameters were determined to evaluate production results:

- individual body weight at 35, 56, 77 and 90 days of age;

- individual weight gains to 90 days of age;

- feed conversion ( $\mathrm{kg} / \mathrm{kg}$ gain);

- mortality and causes of mortality.

At the end of experimental rearing, 6 rabbits weighing between 2500 and $3000 \mathrm{~g}$ were randomly selected from each group. After 24-h feed withdrawal animals were slaughtered in an experimental slaughterhouse in accordance with the current methodology for this group of animals and under the same technological conditions for all the groups. Throughout slaughter and post-slaughter processing, carcasses were individually tagged for easy identification.

Slaughter analysis was performed immediately after slaughter. The following data were collected: fasting body weight, weight of edible parts (carcass without head, liver, heart, kidneys, lungs), weight of offal (fur, blood, legs, digestive tract), weight of head, and slaughter loss. Dressing percentage was calculated as the ratio of hot carcass weight with head to preslaughter weight (after 24-h feed withdrawal) using the following formula:

$$
D P(\%)=C W \times 100 / B W
$$

where:

$D P$ - dressing percentage,

$C W$ - carcass weight without offal $(\mathrm{g})$,

$B W$ - preslaughter weight $(\mathrm{g})$.

Carcass muscling and fatness traits were analysed with regard to tissue composition of the front part, saddle, and the hind part. Determinations were made of chilled carcass weight, tissue composition of the front part (weight of muscle, bone and fat), tissue composition of saddle (weight of muscle, bone and fat), tissue composition of the hind part (weight of muscle, bone and fat) and muscle, bone and fat weights in the entire carcass.

Sensory evaluation of meat was performed on the longissimus dorsi muscle. The muscle was matured at $4{ }^{\circ} \mathrm{C}$ for three days. Samples were heated in water $(0.6 \% \mathrm{NaCl}$ solution) to mild boiling (one part of muscle to two parts of water) to an internal temperature of $85^{\circ} \mathrm{C}$. Cooking was chosen as the meat preparation method because the objective of the evaluation was to pay special attention to aroma of the samples due to the dietary factor applied. The thermal treatment method is best in evoking the intense and typical aroma of rabbit meat. The panel of evaluators did not object to the thermal treatment, which was conducted in these conditions on the grounds that the samples were "undercooked". Thermally treated meat was cooled under cover to room temperature, sliced and evaluated. The evaluation was performed by a panel of 6 assessors with previous sensory evaluating experience. 
Sensory analysis included the evaluation of meat aroma, juiciness, tenderness and palatability on a 5-point scale, as well as overall sensory quality (Tilgner, 1957).

Immediately before slaughter, $5 \mathrm{ml}$ of blood was collected from each rabbit from the marginal vein of the ear to determine the following blood parameters:

- blood count - using an ABC Vet analyser,

- ALT, ASP - with the kinetic colorimetric method, using Pointe Scientific reagents A7526 and A7560.

The tests for Eimeria sp. infection used fresh faecal samples collected in the morning from the flooring. Coproscopy was performed according to a modified McMaster technique with faecal centrifugation, using saturated salt and sugar solution as flotation liquid (Anonym, 1986). Sporulation in 2\% potassium dichromate solution was carried out to differentiate coccidia species (Gundłach and Sadzikowski, 1995), and species were identified based on measurements and morphology of oocysts and sporocysts (Pastuszko, 1963; Anonym, 1986).

Samples of faeces were collected for analysis three times: immediately before weaning (from 34 cages from which animals were taken for the experiment) and at 56 and 90 days of age of rabbits ( 7 bulk samples each).

After slaughter of rabbits at 90 days of age, liver and intestine were examined for pathological changes (Kostro and Gliński, 2005).

The results were analysed statistically with one-factor analysis of variance. Significant differences between the means in groups were estimated with Duncan's multiple range test. The calculations were made using Statistica 7.1 PL.

\section{Results}

Table 1 shows the results of basic nutrient analysis of feed samples. All the nutrients determined in the feeds had a similar level, recommended for this group of animals according to the Nutritional recommendations and nutritive value of feeds for fur animals (Nutritional recommendations, 2011). Animals could correct possible fibre deficiency with straw placed into cages.

Table 1. Results of basic nutrient analysis of feed samples (\%)

\begin{tabular}{l|c|c|c|c|c}
\hline \multicolumn{1}{c}{ Group } & Dry matter & Crude ash & Crude protein & Crude fat & Crude fibre \\
\hline I & 89.31 & 7.15 & 17.55 & 3.35 & 7.45 \\
IN & 89.31 & 7.15 & 17.55 & 3.35 & 7.45 \\
II & 89.16 & 6.69 & 17.37 & 3.37 & 8.83 \\
III & 89.48 & 7.19 & 17.42 & 3.43 & 8.25 \\
IV & 89.13 & 6.30 & 17.36 & 3.44 & 8.66 \\
V & 89.30 & 6.36 & 17.26 & 3.10 & 8.69 \\
VI & 89.57 & 6.38 & 17.32 & 3.27 & 8.45 \\
\hline
\end{tabular}




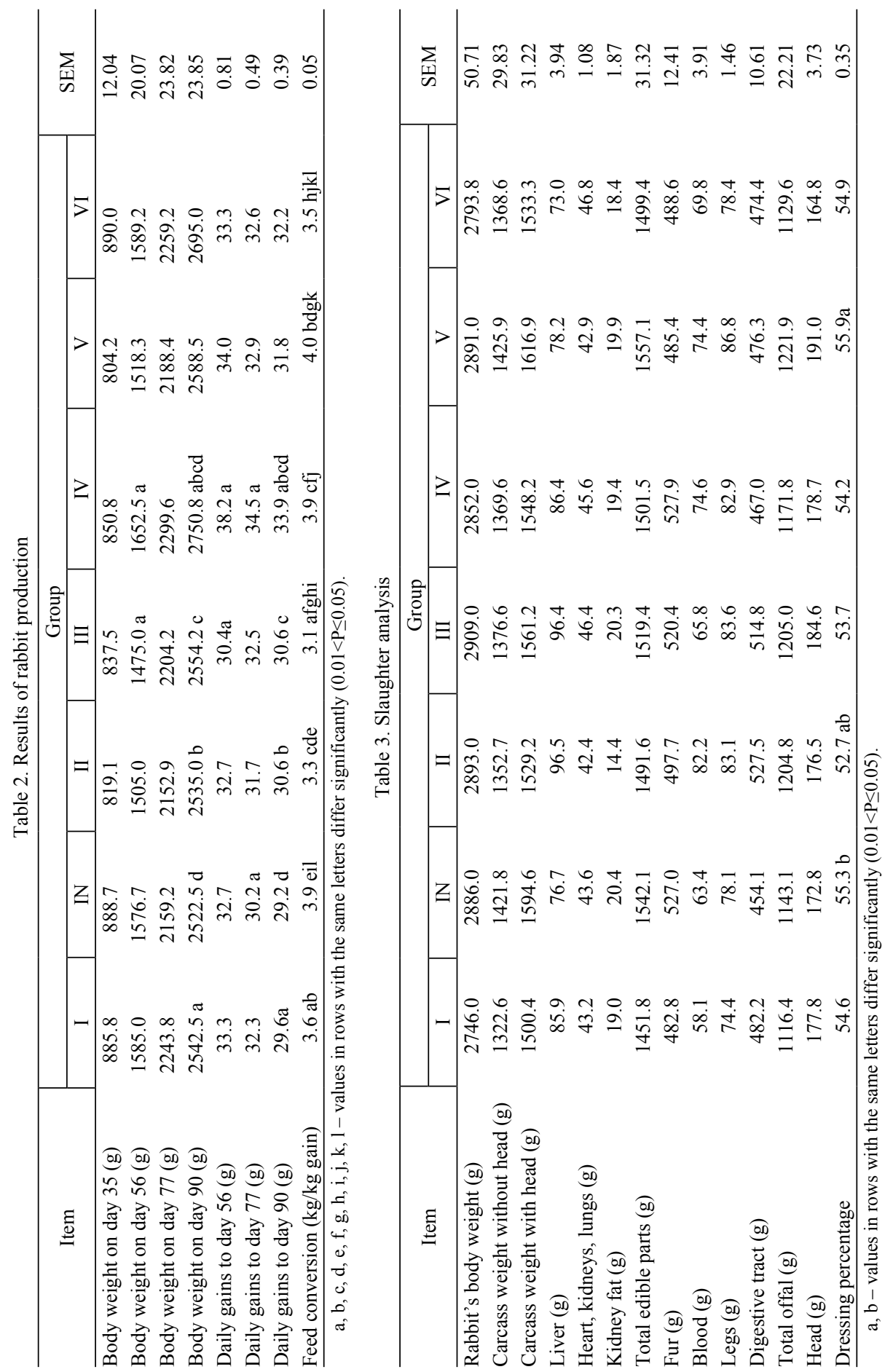


Table 2 presents the body weight of rabbits at 35, 56, 77 and 90 days of age, daily gains and feed conversion over the entire rearing period. The level of feed supplements had no adverse effect on weight gains of animals from weaning to 90 days of age. The highest body weight on slaughter day was obtained by rabbits in group IV. Differences between group IV and groups I, IN, II and III were significant at $\mathrm{P} \leq 0.05$. Similarly, the highest daily gains were found in this group. Significant differences were observed in pellet diet conversion per $\mathrm{kg}$ gain of young rabbits. Rabbits from groups IN, IV and V consumed the most feed, and those from group III the least feed.

Highest dressing percentage (55.9) was noted in rabbits from group V, and the lowest (52.7) in rabbits from group II (Table 3).

Dissection results (Table 4) showed significant differences only in bone weight of the carcass between groups II and IV vs. V. Both in carcass cuts and in the whole carcass, muscle weight was similar in the groups, which shows that the dietary factor had no effect on this parameter.

No statistically significant differences in the sensory evaluation of the analysed meat were found. Neither supplement had any effect on the taste of the meat samples evaluated (Table 5).

Table 6 shows serum AST and ALT levels of rabbits and de Ritis ratio. ALT and AST values were within standard range (Winnicka, 1997), and de Ritis ratio exceeded 1.

Table 6 shows haematological indices of rabbits. No deviations from the reference ranges reported for rabbits were found in any of the groups studied (Kostro and Gliński, 2005).

Parasitological tests performed at the beginning of the study (day 35) showed that most rabbits were infected with intestinal coccidia with no E. stiedai occurring in the liver. The mean number of oocysts per gram of faeces (OPG) was 25748, ranging from 440 to $64800 \mathrm{OPG}$.

The highest number of coccidia oocysts at first sampling (56 days of age, Table 7) was found in groups III (81940 OPG on average), IV (5306 OPG on average) and IN (3340 OPG on average), and the lowest in group I (193 OPG on average). Death losses were recorded in groups III (1 rabbit) and IN (2 rabbits). No anticoccidial drugs were administered to the animals. There were no coccidia-induced lesions in the intestine and liver of dead rabbits. The cause of mortality was colibacillosis, an infectious disease manifested by digestive disorders.

At second sampling (90 days of age, Table 7), the lowest number of coccidia oocysts was found in group III (53 OPG on average) and, like at first sampling in group I (480 OPG on average), the highest number was found in group IN (9520 OPG on average).

Multiple-species infestations occurred in the foundation stock (Table 8). The most frequent coccidia were Eimeria media (41\%) and E. coecicola (32\%), and, among the most pathogenic species, E. intestinalis (9\%) and E. flavescens $(10 \%)$. Mild cases of diarrhoea without mortality were observed in single animals. 


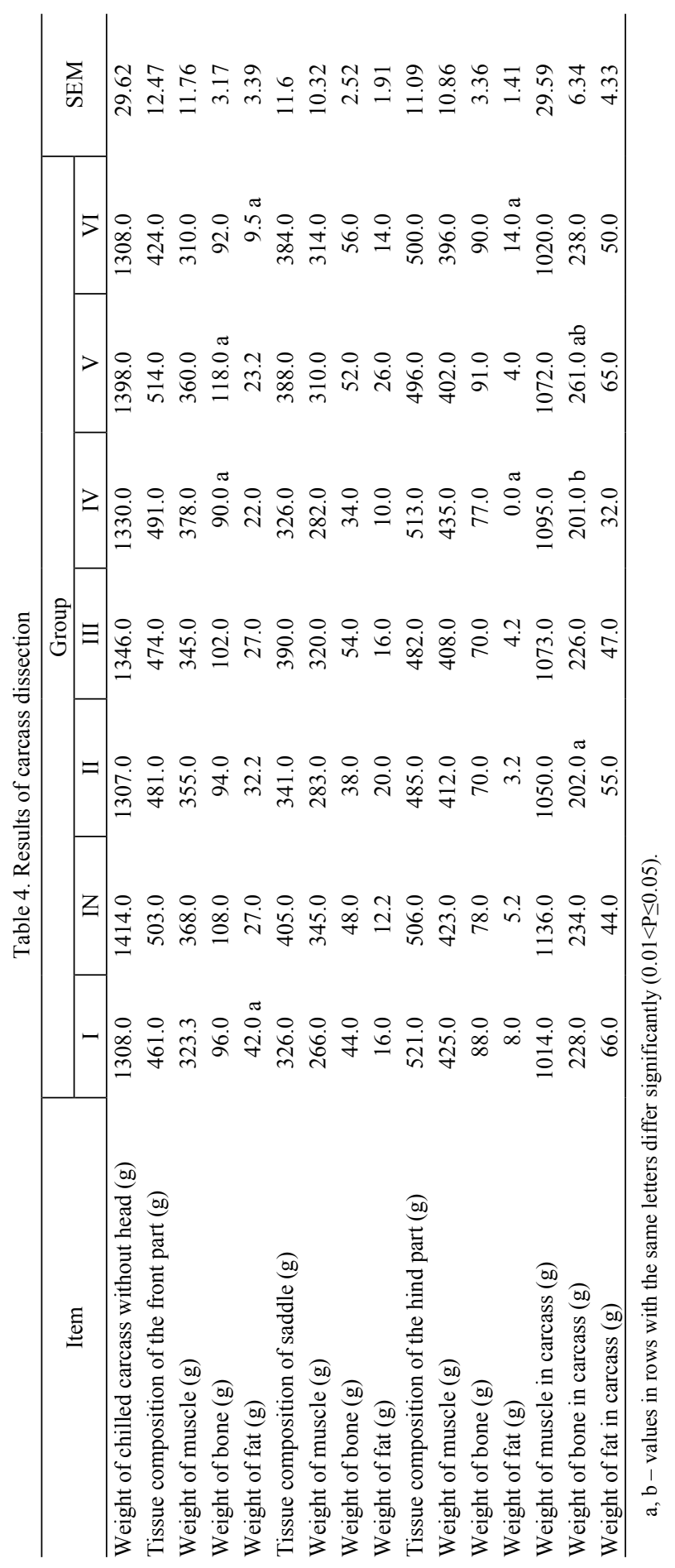



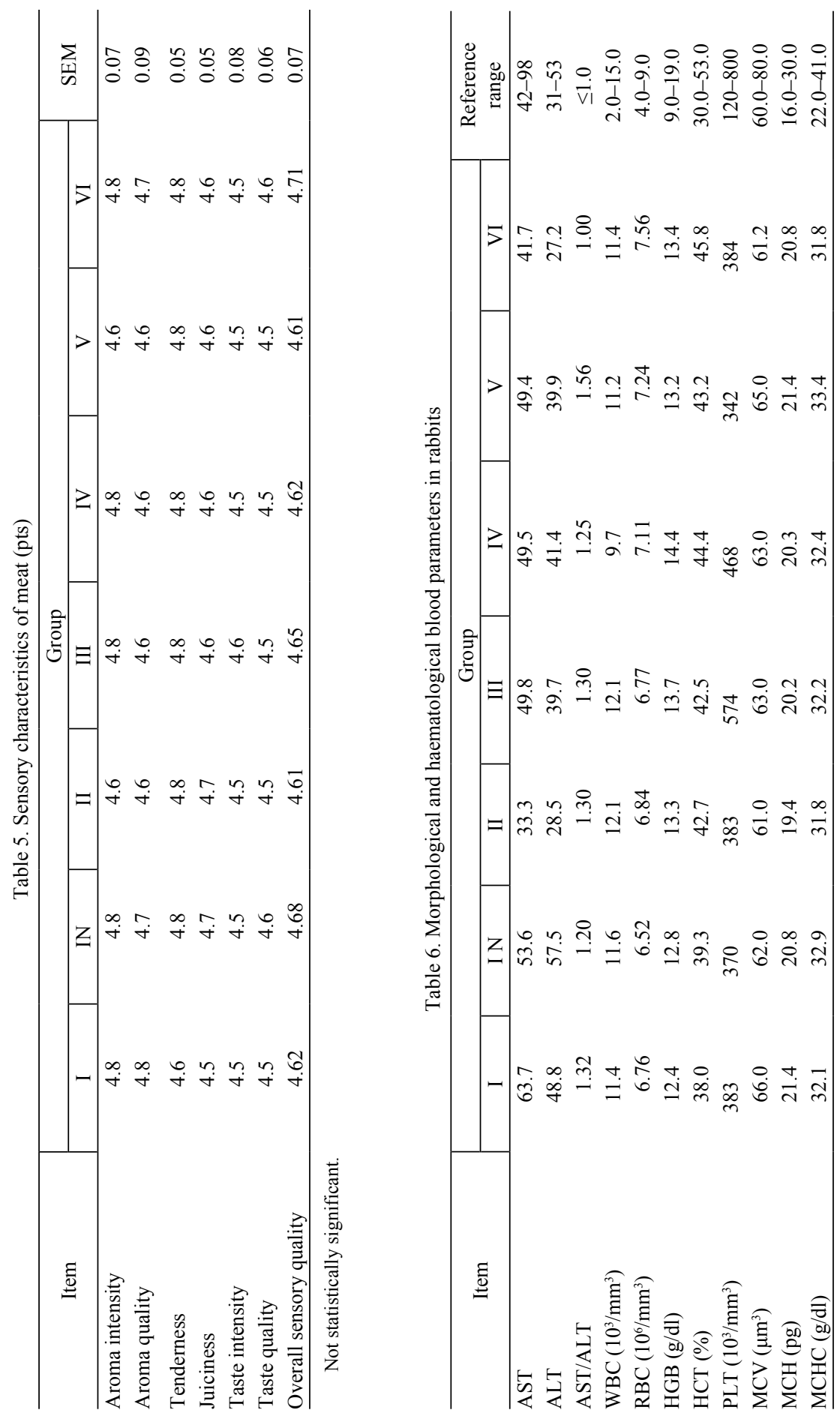


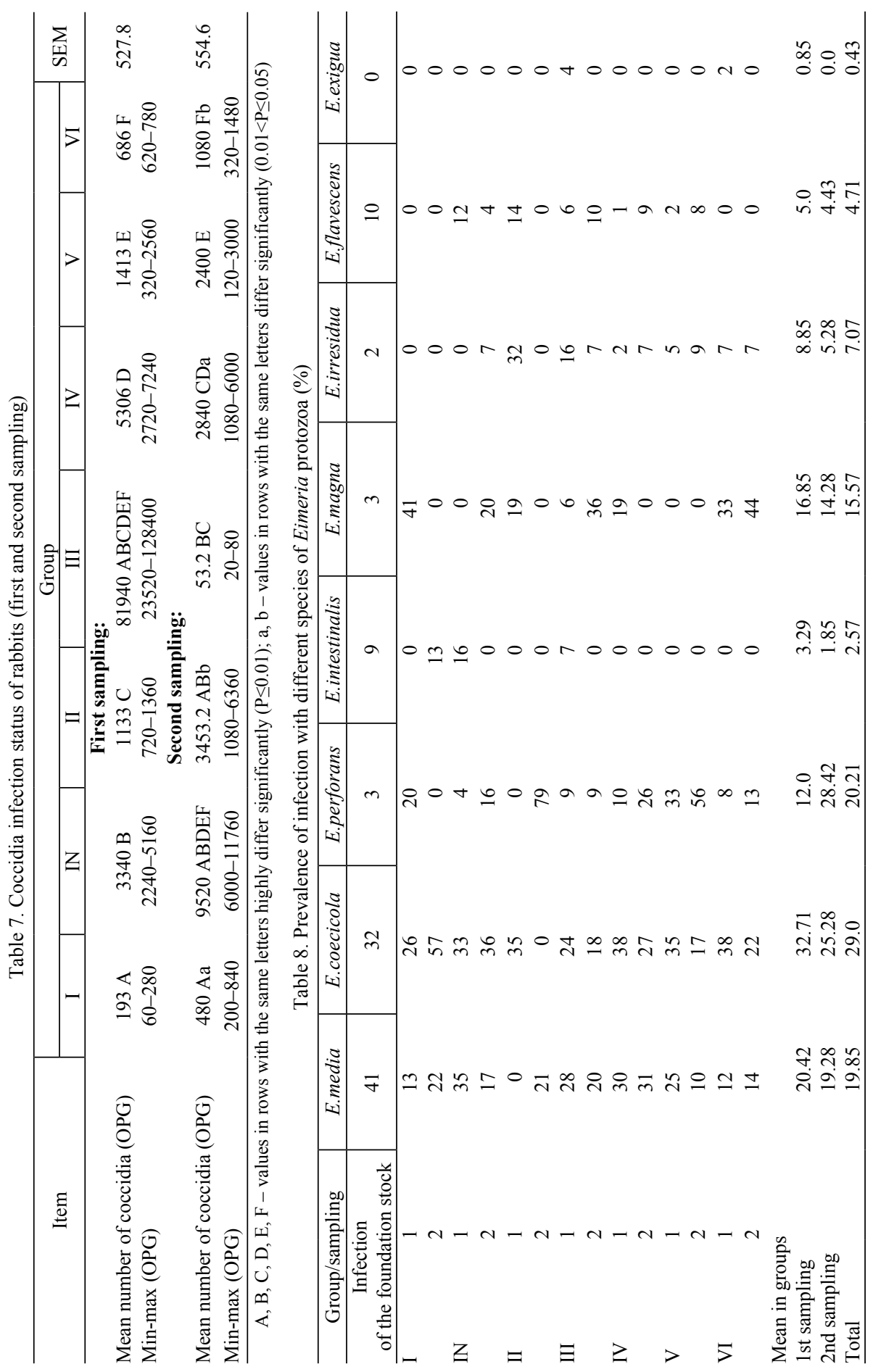


Tests performed at 56 days of age, i.e. 21 days after the experiment began, showed that the highest infection rates were obtained for non-pathogenic $E$. coecicola $(32.71 \%)$ and moderately pathogenic E. media $(20.42 \%)$. The most pathogenic species included E. intestinalis in groups IN (negative control) and III, and E. flavescens in all the groups except I and VI.

Tests conducted at 90 days of age (day 55 of the study) showed the highest infection rates for moderately pathogenic E. perforans $(28.42 \%)$ and for non-pathogenic E. coecicola (25.28\%). Of the most pathogenic species, E. intestinalis was found in group I (control group supplemented with coccidiostat) and E. flavescens in groups IN, III, IV and V.

Postmortem examination of the liver and intestine revealed no characteristic anatomopathological changes characteristic of coccidiosis.

\section{Discussion}

The levels of Bell Gold and Bell Premium concentrates had no negative effect on the growth of animals during the period from weaning to 90 days of age. The daily gains, which exceeded $30 \mathrm{~g}$ in all the experimental groups, are considered high.

The growth efficiency of rabbits can be measured in terms of the basic indicators of herd performance. Of these, dressing percentage is the first parameter characterizing the efficiency of a rabbit population in producing rabbit meat. Like meat quality, this indicator depends on many factors such as breed, age, sex, weight of slaughtered animals, and feeding and housing system. The highest dressing percentage was found in rabbits from group V (55.9) and the lowest in those from group II (52.7). Pla et al. (2008) report that for this breed of rabbits, a dressing percentage of 55.5 is regarded as very good. Similar values are suggested in the standards reported by the World Rabbit Science Association (WRSA). The dressing percentage values obtained in all experimental groups (from 52.7 to 55.9) are higher than those reported for this breed of rabbits raised in Poland by Chwastowska-Siwiecka et al. (2011) - 52.45 and Maj et al. (2011) - 48.17. According to Gugołek et al. (2008), dressing percentage of New Zealand White rabbits fed a pellet diet and kept in confinement is about 51.5.

In the present study, no differences were found in the sensory evaluation of meat. Despite being added daily to rabbit diets, neither the Bell Gold nor the Bell Premium preparation had a negative effect on the aroma, palatability, tenderness and juiciness of meat.

The ALT and AST values were within the standard range reported by Winnicka (1997). However, the AST/ALT ratio (de Ritis ratio) is important in diagnosis. It is accepted that in healthy animals, the activity of aspartate aminotransferase is higher than that of alanine aminotransferase (Bogusławska-Tryk et al., 2008), which means that this ratio should be greater than unity. Values less than $0.9 \mathrm{IU} / \mathrm{L}$ are most often indicative of diseases of the liver parenchyma. Of course, to obtain conclusive evidence of the presence of pathological lesions in the liver, the alanine aminotrans- 
ferase parameter should be interpreted in conjunction with other clinical manifestations, indeed with histopathological findings. In all the groups studied, the AST/ALT ratio exceeded 1, and the analysed livers showed no changes suggestive of the presence of Eimeria stiedai oocysts, as confirmed by sporulation results.

With advancing coccidiosis in animals, blood count examination shows signs of anaemia, in addition to external changes such as bristling and fading of hair, enlargement of abdominal integument, and bloat. Parasites activate platelets in peripheral blood, and this activation may be manifested by changes in their number and morphological parameters (Kostro and Gliński, 2005). No changes in blood parameters were ascertained in all studied groups.

In general, the infection rate of rabbits prior to the experiment was comparable with the results of an earlier study with the same herd, and the dynamics of infestation during rearing was similar despite the addition of coccidiostat to the feed (Nosal et al., 2009).

According to Pakandl (2009), the number of oocysts shed is not correlated with disease incidence, which is associated with differences in the pathogenicity of different Eimeria species. Nevertheless, a count of less than 2000 oocysts per gram of faeces is considered a safe infestation level. This level was observed for both samplings in groups I and VI, which shows the effect of the experimental factor on the parameter studied (Table 7). However, the presence of E. intestinalis and other coccidial species in the faeces of animals from group I, in all samplings, may be indicative of drug resistance of coccidia (Table 8).

The highest number of oocysts during the experiment was found at the first sampling in group III (81940 oocysts per gram of faeces) and at the second sampling in group IN (9520 oocysts per gram of faeces). The low OPG count at the second sampling in animals from group III - lower than in the control group receiving the coccidiostat - would suggest that they became immune after recovering from the disease. Despite such a high intensity of infection, no clinical signs of the disease were found in animals from these groups.

A study by Ramisz (1988) confirmed no disease symptoms when the intensity of infection was 550000 oocysts per gram of faeces.

Eleven species of coccidia, differing in the morphology of sporulated oocysts, sporulation time, location in the host's body, and pathogenicity were described in rabbits (Pakandl, 2009). Eimeria exigua, E. irresidua, E. magna, E. media, E. perforans and $E$. vejdovskyi establish themselves in the small intestinal epithelial cells, and Eimeria coecicola, E. flavescens and E. intestinalis and E. piriformis in epithelial cells of the small and large intestine. Eimeria stiedai colonize the epithelial cells of the hepatic bile ducts. E. intestinalis, E. flavescens and E. stiedai are the most pathogenic species, with $E$. intestinalis causing the most extensive postmortem lesions, and E. perforans is the least virulent. Mostly duodenal and jejunal lesions occur with $E$. perforans, E. media and E. irresidua infections, ileal lesions with E. magna and E. intestinalis infections, and cecal and colonic lesions with E. flavescens infection (Kostro and Gliński, 2005). Eimeria coecicola, E. exigua and E. vejdovskyi are considered non-pathogenic species, but recent studies (Metwaly et al., 2011; Al-Quraishy et al., 2012) contradict this, indicating that E. coecicola causes 
lesions outside the intestine (in the liver and kidneys). No such research was done for the other species of intestinal coccidia.

Mild cases of diarrhoea without death losses were observed in single animals from groups I, II, IV and V. Such symptoms are often observed during the weaning of rabbits from mothers, where stress, caused by a change in housing conditions, tattooing, and protective vaccinations, may increase the symptoms associated with digestive disorders. The supplementation of Bell Gold and Bell Premium preparations based on garlic and oregano oils, which have strong antibacterial, antiviral, antifungal, antiparasitic, anti-inflammatory and disinfecting properties, enhanced the animals' immunity and made the disease less severe. Similar findings were obtained in studies investigating the efficacy of garlic in rabbits and mice (Abu-Akkada et al., 2010; Dkhil et al., 2011) and of mustard in rabbits (Gugołek et al., 2011) as preparations for prevention of coccidiosis.

In summary it may be stated that the different levels of Bell Gold and Bell Premium supplementation in the complete diets for rabbits had a positive effect on the weight gains of young rabbits during the study from 35 to 90 days of age. Dressing percentage values in all experimental groups were higher than those reported for this breed of rabbits raised in Poland, and both feed supplements had no effect on the taste of meat samples. Properly formulated rations reduced the intensity of coccidial infections. The Bell Gold and Bell Premium preparations could also protect the animals against secondary bacterial and viral infections, which usually accompany coccidiosis and are a common cause of mortality. The present results suggest that the herb extracts can be successfully used in prophylaxis as natural alternatives to coccidiostats in feeds.

\section{References}

A bu - A k k a d a S.S., Od a S.S., A sh maw y K.I. (2010). Garlic and hepatic coccidiosis: prophylaxis or treatment? Trop. Anim. Health Pro., 42: 1337-1343.

A 1-Quraishy S., Metwaly M.S., Dkhil M.A., Abdel-Baki A.S., Wunderlich F. (2012). Liver response of rabbits to Eimeria coecicola infections. Parasitol. Res., 110: 901-911.

A nonym (1986). Manual of veterinary parasitological laboratory techniques. Reference book 418. Ministry of Agriculture, Fisheries and Food, London.

Bogusławska-Tryk M., Szymeczko R., Piotrowska A., Bulikowska K., Kub a c k i S. (2008). Protein metabolism parameters in blood serum of polar foxes female in relation to age of animals. Med. Weter., 64: 720-722.

Chwastowska-Siwiecka I., Kondratowicz J., Winarski R., Śmiecińska K. (2011). Slaughter value and selected quality attributes of meat of meat rabbit breeds (in Polish). Żywność. Nauka. Technologia. Jakość, 2 (75): 136-147.

Dkhil M.A., Abdel-Baki A.S., Wunderlich F., Sies H., Al-Quaraishy S. (2011). Anticoccidial and antiinflammatory activity of garlic in murine Eimeria papillata infections. Vet. Parasitol., 175: 66-72.

Gugołek A., Lorek M.O., Kowalska D., Janiszewski P., Daszkiewicz T. (2008). Effect of housing and feeding conditions on the production results and coccidiosis infection rates of New Zealand White rabbits (in Polish). Rocz. Nauk. PTZ, 2 (4): 39-44.

Gugołek A., Kowalska D. Konstantynowicz M., Strychalski J., Bukowska B. (2011). Performance indicators, health status and coccidial infection rates in rabbits fed diets supplemented with white mustard meal. Ann. Anim. Sci., 11: 425-432. 
Gund $\nmid$ a ch J.L., S a d zi k ow ski A.B. (1995). Diagnostic and control of parasitic invasion of animals (in Polish). Wydawnictwo AR, Lublin.

Kostro K., Gliński Z. (2005). Rabbit diseases - basics of husbandry and breeding (in Polish). PWRiL, Warszawa, 1-337 pp.

L i c o is D. (2004). Domestic rabbit enteropathies. Proc. 8th World Rabbit Congress, invited paper. Puebla, Mexico, pp. 385-403.

Maj D., B i eniek J., B e kas Z. (2011). Effect of age and sex on slaughter traits in New Zealand White rabbits (in Polish). Rocz. Nauk. PTZ, 7: 59-67.

Metwaly M.S., Dkhil M.A., A l-Qura ishy S. (2011). Renal tissue damage due to Eimeria coecicola infection in rabbits. Afr. J. Microbiol. Res., 5: 1349-1354.

Nos al P., Kow a 1 J., N ow o s a d B., B i en i e k J., Kow al sk a D. (2009). Dynamics of endoparasite infections in rabbits at different breeding regimes (in Polish). Wiad. Parazytol., 55: 173-177.

Nutritional recommendations and nutritive value of feeds (fur animals) (2011). Ed. A. Gugołek (in Polish). Instytut Fizjologii i Żywienia Zwierząt, Jabłonna.

P a k a n d 1 M. (2009). Coccidia of rabbit: a review. Folia Parasitol., 56 (3): 153-166.

P a st u s zk o J. (1963). Rabbit coccidiosis in Poland (in Polish). Pol. Arch. Weter., 8: 129-139.

P 1 a M., Z o m e no C., Her $n$ a n d e z P. (2008). Effect of the dietary $n-3$ and $n$-6 fatty acids on rabbit carcass and meat quality. 9th World Rabbit Congress on Meat Quality and Safety, Verona, Italy, pp. $1425-1429$.

R a m i s z A. (1988). Prevention and control of coccidiosis in animals (in Polish). Wiad. Parazytol., 34: $551-555$.

Szkucik K., Paszkiewicz W. (2011). Morbid traits and qualitative changes in rabbits slaughtered in Poland between 2000-2010 (in Polish). Med. Weter., 67 (10): 690-693.

T ilg n e r D.J. (1957). Sensory evaluation of food (in Polish). WPLiS, Warszawa.

Winnicka A. (1997). Reference values of basic laboratory tests in veterinary research (in Polish). Wyd. SGGW, 1: 3-115.

Accepted for printing 13 IV 2012

DOROTA KOWALSKA, PAWEŁ BIELAŃSKI, PAWEŁ NOSAL, JERZY KOWAL

Naturalne alternatywy dla kokcydiostatyków w żywieniu królików

\section{STRESZCZENIE}

W chowie królików poważnym problemem zdrowotnym, produkcyjnym i ekonomicznym z uwagi na powszechne występowanie jest kokcydioza wywoływana przez pierwotniaki z rodzaju Eimeria. Zgodnie z rozporządzeniem (WE) nr 1831/2003 Parlamentu Europejskiego i Rady w sprawie stosowania kokcydiostatyków jako dodatków paszowych mają one być wycofane do dnia 31 grudnia 2012 roku. Dlatego poszukuje się obecnie naturalnych alternatyw kokcydiostatyków, które mogłyby powstrzymać rozwój tej choroby. Celem prowadzonych badań było rozpoznanie sytuacji inwazjologicznej w stadzie króliczym przed i po zastosowaniu naturalnych zamienników powszechnie stosowanych preparatów kokcydiobójczych oraz określenie wpływu tych dodatków na wyniki produkcyjne i jakość mięsa królików. Zastosowane dodatki paszowe oparte zostały o naturalne olejki oregano i czosnku, które dodane w różnych proporcjach do pełnoporcjowych mieszanek paszowych wpłynęły pozytywnie na przyrosty młodych królików w okresie trwania badań od 35. do 90. dnia życia. Wydajność rzeźna we wszystkich grupach doświadczalnych była wyższa od podawanych dla królików rasy NB, a zastosowane dodatki paszowe nie miały wpływu na smak ocenianych próbek mięsa. Odpowiednio dobrane dawki stosowanych koncentratów zmniejszały intensywność zarażenia kokcydiami, zabezpieczając jednocześnie zwierzęta przed wtórnymi zakażeniami bakteryjnymi i wirusowymi, które zwykle towarzyszą kokcydiozie i są z reguły przyczyną upadków. Wyniki badań sugerują, że użyte ekstrakty ziołowe mogą być z powodzeniem stosowane w profilaktyce, jako naturalne zamienniki kokcydiostatyków w paszy. 